\title{
Green Production Associations Study between Brand Trust, Satisfactory Degree and Re-purchase Intention
}

\author{
$\mathrm{Xi}$ Chen ${ }^{1, \mathrm{a}}$ and Fangping $\mathrm{CaO}^{1, \mathrm{~b}^{*}}$ \\ ${ }^{1}$ Department of Economics and Management, Beijing Forestry University, No.35, Tsinghua East \\ Road, Haidian District, Beijing, China \\ achenxi_199308@163.com, bcfp_888@126.com \\ * The corresponding author
}

Keywords: Green Production; Brand Trust; Satisfactory Degree; Re-Purchase Intention

\begin{abstract}
This paper takes the consumers who have purchased green products in Taiwan as the research object, and choose the three variables of brand trust, satisfaction and willingness to buy, and use the confirmatory factor analysis and structural equation method to analyze the valid questionnaires Consumer green consumption behavior. The results show that the brand trust of green products has a positive impact on satisfaction, and brand trust will indirectly affect the willingness to repurchase. This paper puts forward some relevant discussions and suggestions, hoping to provide strategies and references for the development and management of green products related industries, and hoping to make some contribution to the green product consumption theory and practice.
\end{abstract}

\section{Introduction}

In recent years, with the deteriorating global environment, the conflict between economic activities and the natural environment has aroused widespread concern in the community, almost all people realize that the excessive consumption of resources and energy, the destruction of the ecological environment is affecting the economy Sustainable development, the protection of the environment has been urgent, in this macro context, the implementation of green management has become an inevitable trend[1]. In the production and operation of enterprises and product consumption, should take a modest development of natural resources and environmental-friendly production and consumption behavior. The Green products are products that are harmless to the health of the consumer from the point of manufacture, sale, use of the product and can minimize the harm to nature (Elkington \& Hailes, 1993; Peattie, 1992) [2-3]. The scope of this study is mainly food, such as green food, natural food and organic food. In order to slow down the destruction of nature and the environment, governments, businesses and consumers are beginning to attach importance to and encourage the purchase of environmentally friendly products. Especially, governments have been actively promoting the certification of green products, and environmental labeling or organic signs are often used as one of the ways to identify green products (successful university green product testing laboratories, 2012; D'Souza, 2000) [3-4].

Many companies are actively developing and manufacturing green-related products, and the use of products or services, packaging and advertising marketing to consumers of this green product marketing messages to inform the public consumer green products on the Earth's environment friendly to hope Change the consumer's inner business and brand image, while strengthening the consumer confidence in the green product brand. For example, some brands of enterprises claim that their own green products produced by the production process is environmentally friendly, the use of organic fertilizers, etc., in the enterprise or brand advertising and marketing at the same time, consumers virtually have increased their confidence in green products, and The enterprise to give a positive evaluation. It can be seen that brand trust is of great significance to the promotion and development of green products, and it is also the first motivation of this paper.

In the study of consumer behavior, often discuss the satisfaction and re-purchase willingness. Customer satisfaction refers to the consumer's experience of buying and consuming all the products 
and services and accumulating over time (Anderson, Fomell, \& Lehmann, 1994) [6] and the willingness to buy a product for the consumer Probabilities, possibilities and wishes (Dodds, Monroe, \& Grewal, 1991) [7]. In the past, the higher the satisfaction of consumers, the higher the degree of loyalty and repurchase (Lai, Griffin \& Babin, 2009; Russell-Bennett, McColl-Kennedy \& Coote, 2007) [8-9]. Companies are thinking about how to improve consumer satisfaction in order to increase the willingness to buy. Therefore, it is the second motive to explore the relationship between satisfaction and the willingness to buy.

Although the trust of the brand is an important variable in this study, is it possible to influence the willingness of consumers to purchase green products through the mediating role of satisfaction? If the possibility of mediating the variables is ignored, the consumers can not fully explain the Behavior pattern. Therefore, this study will explore the satisfaction of brand trust and re-purchase intention between the existence of intermediary relationship.

The purpose of this study is to explore the impact of green products on the impact of these variables, and according to the results of the study on the green product industry, the relevant management strategies and recommendations, and further enrich and supplement the green product consumption theory and practice.

\section{Literature Review}

Green Products. Green product (green product) is a widely regarded issue in recent years, the International Organization for Standardization (2013) [10] in the 1997 announcement of the ISO 14024 standard green products defined as: based on life cycle theory, with the overall environmental advantages of the product with the service. In other words, the food which can save resources, reduce pollution and do not destroy the ecological environment are green products. Therefore, green products not only contain the spirit of pollution prevention, but also on behalf of the producers of products, the environment to bear the responsibility, and regard the pursuit of sustainable development as the goal. Peattie (1992) [3] defines green products as: green products that are products or services that provide greater advantages over the environment and society than to traditional or competitive brands in the past. Lockie, Lyons, Lawrence and Grice (2000)[11] believed that fresh, non-chemical additives, nutrient-rich, natural food, and environmentally sustainable products are green products. This study defines green products as food products that are harmless to the health of consumers from the production, sale, and consumption of food and can minimize the harm to the earth. They can be called green products

Nash (2009) [12] also pointed out that when most consumers are willing to buy green products, the produce market can be forced to encourage manufacturers to change their thinking and put into green production and marketing, thereby improving the product from production to consumption process. Fan Yiwen, Fang Yuxian and Cai Mingfeng (2012) [13] found that if the consumer has a green behavior attitude, it will affect the green product re-purchase intention and green Product recommendation will in a study of environmental behavior and consumer behavior to explore the study of green consumption. Lin and Huang (2012) [14] in a study of the impact of green product selection factors - consumer value theory based research also found that if consumers are more concerned about environmental issues are more willing to choose green products. The green product of this study is a kind of food that follows the laws of nature and conforms to the natural ecological system and uses natural resources.

Brand Trust. Brand trust means that consumers are willing to take the initiative and trust the products offered by the brand (Chaudhuri \& Holbrook, 2001) [15]. When consumers face unfamiliar brands or products, the sense of trust in the consumer behavior plays a very important role. Chaudhuri \& Holbrook (2001) [15] also pointed out that brand trust is the consumer willing to take the initiative to believe and trust the brand to provide the product to maintain. Delgado-Ballester (2004) [16] argues that brand trust refers to the persistence of consumer safety in their interaction with the brand, based on the brand's reliable and trustworthy perception of consumer interests and benefits. And when consumers have a trust in a particular brand, they will positively affect consumers' buying loyalty and attitude loyalty (Chaudhuri \& Holbrook, 2001) [15]. 
So in order to enhance the purchase of consumers, increase consumer confidence in the brand is necessary.

Ha and Perk (2005) [17] used online shopping consumers as the object of study, to explore the network experience, familiarity, satisfaction and brand trust relevance, the results show that brand trust and network experience, satisfaction and familiarity with a positive Medium, highly relevant. Delgado-Ballester (2004) [16] thought that their study uses random sampling to collect samples of two different types of products and uses the competitive mode method to measure the scale. The results show that the brand trust two potential facets the variable, which contains the brand trustworthiness and brand intention two facets. Delgado-Ballester and Munuera-Alemán (2005) [18], based on the Delgado-Ballester (2004) [16] brand trust scale, explored the relevance of overall satisfaction, brand trustworthiness, brand intention, brand loyalty and brand equity, and shows that the two potentials of brand trust will positively affect brand loyalty and will indirectly affect brand equity through brand loyalty.

Brand trust for the newly established changes in the field of consumer research has been gradually discussed, but few studies will be applied to the brand of green products on the issue, so in order to strengthen the understanding of the green product brand trust effect, This study will be brand trust to join the green product consumer behavior model to explore, hope for the green product industry to provide relevant brand strategy and recommendations.

Satisfaction. Satisfaction refers to the customer through the use of products or services, the service or product generated by a comprehensive assessment. Anderson, Formell and Lehmann (1994)[6] point out that overall customer satisfaction is the overall evaluation of the consumer's overall experience of purchasing and consuming a product or service and accumulating over time. Johnson and Formell (1991) [19] argue that customer satisfaction is the overall evaluation of the product or service performance provided by the consumer to the company. Blackwell, Miniard and Engel (2001) [20] define satisfaction for customers after using the product, evaluate the consistency between the performance of the product and the purchase before the two, when the two are consistent, the customer will be satisfied. He and Song (2009) [21] use an example of the travel products provided by the traveler for the travel agency, confirm the relationship between the perceived service quality, the perceived value, the satisfaction and the purchase intention of the tourists. The result indicates that the purchase intention of the tourists will be directly affected by satisfaction.

It is very important to understand the degree of satisfaction of the product for the product. Therefore, this study will discuss the change of the satisfaction degree into the green product consumer behavior mode, hoping to help strengthen the enterprise's willingness to repurchase the product Prediction.

Re-purchase Intention. Repurchase intention is a decision-making behavior, is the process of consumers to buy items. That is, when consumers collect and evaluate the various products related to the advantages and disadvantages of products and brands to meet certain needs, the final decision to buy a product. Zeithaml (1988)[22] argues that consumers' willingness to repurchase is subject to personal cognitive value, objective price, internal and external characteristics, and cognitive quality. Dodds et al. (1991) [7] defines the probability, likelihood and willingness of a remarketing intention for consumers to buy a product. Moorman, Zaltman and Deshpande (1992) [23] defined the willingness to buy as a consumer attempt to buy a product, and when the consumer chooses "I may buy" or "I will buy", the news promised to re-purchase intention. Schiffman and Kanuk (2000) [24] argue that the greater the willingness to buy when the consumer is willing to buy, the greater the likelihood that the consumer will actually buy. So the re-purchase intention is a measure of the degree of behavior indicators, consumers do not want to buy high consumer will buy, but the opportunity to increase the purchase, we can see that the re-purchase intention in the consumer behavior is a very important Research variables, so this study will be included in this variable as a variable to explore, and operational definition of the re-purchase of this study is intended for consumers to buy or re-purchase the possibility of green products. 
The Relationship Between Brand Trust, Satisfaction and Re-purchase Intention. Ha and Perks (2005) found that brand trust and satisfaction in consumer behavior were highly correlated. Wu Zongyou (2008) also found that trust would positively affect satisfaction. (Eg, Lee, Graefe \& Burns, 2007; Oh, 1999) [26-27] think that it is possible to judge that trust can be regarded as a matter of satisfaction before the trust is a part of the connotation of service quality. Many studies have found that the quality of service is the predecessor of satisfaction dependent variable. When consumers have a trust in a particular brand, they will positively affect consumers' buying loyalty and attitude loyalty (Chaudhuri \& Holbrook, 2001) [15]. Consumers may be due to the trust of the brand and then enhance the willingness to repurchase the product (Lin Nanhong et al., 2007) [28]. It can be deduced that consumers' satisfaction and willingness to repurchase may be higher when consumers have a higher level of trust in green products. Therefore, this study presents the hypothesis of one or two:

H1: consumer green product brand trust has a positive impact on satisfaction.

$\mathrm{H} 2$ : consumer green product brand trust has a positive impact on repurchase intention.

Brakus, Schmitt and Zarantonello (2009) [29] point out that consumer satisfaction with the product will positively affect its loyalty. There are also studies found that consumer satisfaction will positively affect their behavioral intentions (Lai, Griffin \& Babin, 2009[8]; Yoon, Lee\& Lee, 2010[30]). And satisfaction is one of the most important variables affecting the repurchase intention (Lai et al., 2009; Russell-Bennett et al., 2007) [8-9]. From the above literature can be inferred, when the consumer satisfaction with the product the higher, then the re-purchase may be higher. Therefore, the proposed hypothesis of the third study:

H3: consumer green product satisfaction has a positive impact on repurchase intention.

Factors that influence consumption decisions and behavior, brand trust is considered to be one of the important factors (Chaudhuri \& Holbrook, 2001[15]; Delgado-Ballester \& Munuera-Alemán, 2005[18]), and satisfaction will directly affect the respondents' positive recommendation (Hosany $\&$ Martin, 2012) [31].Consumers for the brand's trust, may be through the intermediary role of satisfaction, and thus affect the consumer to buy green products will, so this study proposed the following hypothesis four:

H4: Consumers' satisfaction with green products has an intermediary effect between brand trust and repurchase intention.

\section{Research Methods}

Research Architecture. Based on the literature review and hypothesis deduction, this paper leads to the positive impact of brand trust and the willingness to repurchase. Satisfaction has a positive impact on repurchase intention, and satisfaction plays an intermediary role in brand trust's impact on repurchase intention, its conceptual architecture is shown in Fig. 1.

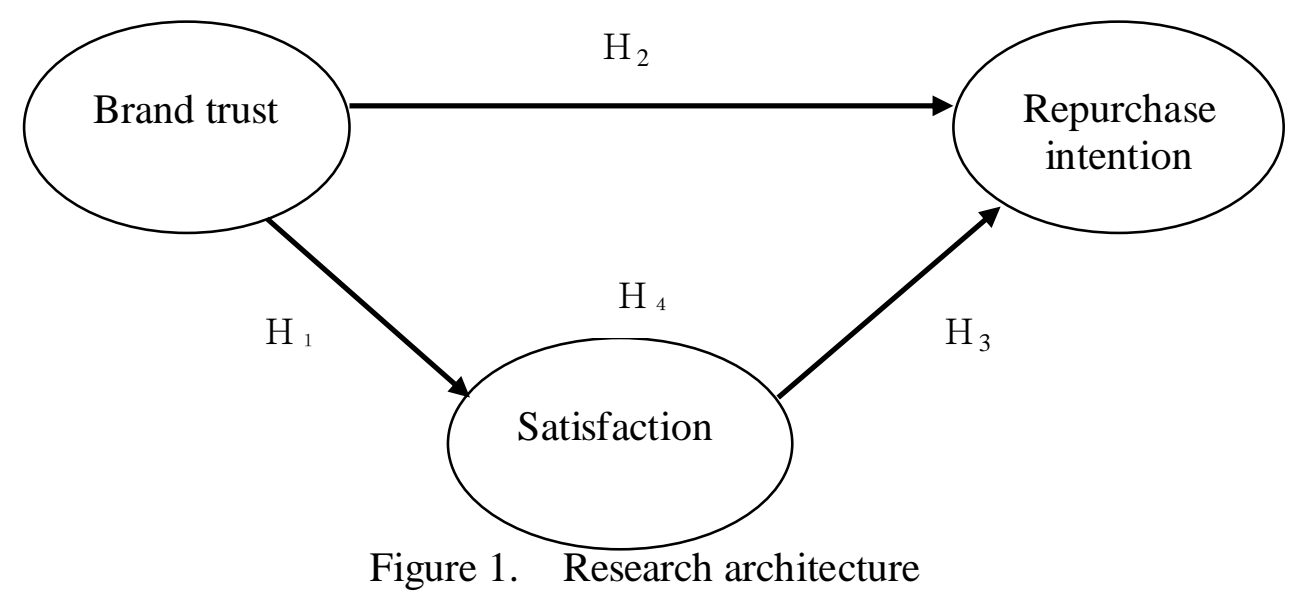


Questionnaire Design. The research variables mainly include green food knowledge, ecological emotion and willingness to repurchase. The research method is based on the quantitative questionnaire survey, the total question of the questionnaire is 22 questions, and the Likert-type five-point scale is used to measure The Score from 1 to 5 points from "very disagree" to "very agree". The question of brand trust is a total of 4 questions. The questionnaire is mainly revised from Chaudhuri \& Holbrook (2001) [15], which is based on the research content. The purpose is to measure the degree of consent of consumers to the trust of green products. According to individual self-perception The higher the score, the higher the confidence of the individual about the brand of green products. A total of four questions were questioned, and the scale was mainly revised from Oliver (1980) and Brakus et al. (2009) [29]. Measure the satisfaction of consumers for green products, according to individual self-perception, the higher the score that the higher the satisfaction of individuals for green products. A total of three questions were asked, and the scale was revised from Grewal et al(1998) [7]. To measure the extent to which consumers were willing to buy green products. The higher the score, the higher the individual would expect the purchase of green products. In addition, the questionnaire finally asked the subject's background information, including sex, age, education, occupation, average monthly income, often go to the green products of the store, how long et al.

Descriptive Statistics. In this study, sample sampling was used to facilitate the sampling. This study is mainly based on the purchase of green food consumers as the object of study. The survey was mainly carried out in Taiwan. To issue green food, organic food and other stores on-site survey method to issue the questionnaire. A total of 481 copies were recovered, the blank questionnaires were eliminated, the questionnaires were hastily checked or incomplete, and the questionnaire with omissions, violation and consistency was removed. The valid questionnaires were 416 and the effective questionnaires were $86.49 \%$.

data processing and analysis

In this study, SPSS 12.0 statistical software was used to analyze the background data of the subjects, and the distribution of demographic variables and characteristics was analyzed. Using the LISREL 8.7 to confirm the factor analysis and structural equation analysis, the maximum likelihood estimation method was used to estimate the causal relationship between the variables.

\section{The Results of the Study}

Sample Characteristics. The number of valid recovery samples was 416 , of which the majority of women accounted for $58.2 \%$ and men accounted for $41.8 \%$, showing that the majority of female buyers were mostly female. The age was mainly distributed between 21 and 30 years old, 41 to 50 years old, accounting for $26.3 \%$ and $25.9 \%$ of the total. The level of education is mainly high school / vocational majority, accounting for $38.9 \%$ of the overall; followed by college / school, accounting for $25.5 \%$. Occupational distribution mainly to students, businessmen, attendants majority, each accounted for $25.2 \%, 24.1 \%, 23.6 \%$. It can be seen that the purchase of green products, consumer distribution of a wide range of occupational. Among them, the average monthly income of individuals in less than 20,000, accounting for $32.6 \%$; followed by 40,000 to 60,000 , accounting for $24.2 \%$, indicating that the purchase of green products may not be high-income groups. Sample characteristics show that often go to the green product store (check) to Rene (Taiwan organic food company), each of the 48 people have been to; followed by St. De Coase (Taiwan), 36 people per 100 people have to This purchase of green goods; other such as non-toxic home, housewife Union Every hundred people have nearly 18 and 15 people had to go to buy goods. The consumption rate of green products mainly fell by $36.4 \%$ in one month or two, and then $27.3 \%$ for one month or more, $19.6 \%$ for green products and $16.7 \%$ for each week.

The Validation Factor Analysis. In this study, confirmatory factor analysis (CFA) test scale validity and reliability. The results of the confirmatory factors for each construct are shown in Table 1. The average fitness of the measurement model is $\chi^{2}=186.78, \mathrm{df}=41, \chi^{2} / \mathrm{df}=4.55$, GFI $=0.90$, $\mathrm{CFI}=0.94, \mathrm{IFI}=0.94, \mathrm{NFI}=0.96, \mathrm{SRMR}=0.026, \mathrm{RMSEA}=0.068$, it shows that the 
compatibility between the sample data and the model has reached an acceptable standard. Although the chi-square value $\left(\chi^{2}\right)$ is significant, the chi-square value is divided by the degree of freedom $\left(\chi^{2}\right.$ / df $=4.55)$ less than 5 suggested by Bagozzi and Yi (1988), showing that the model has a good fit. In addition, other indicators such as GFI, CFI, IFI and NFI are higher than or similar to the recommended value of 0.9, and SRMR and RMSEA is lower than the standard value of 0.1 (Hair, Anderson, Tatham, \& Black, 1998) ${ }^{[33]}$. In terms of convergence validity, the observed variables reach a significant level $(\mathrm{t}>1.96, \mathrm{p}<0.05)$, and the factor load of the estimated parameters is higher than the judgment criterion of 0.50. The significant factor load indicates that the scale used in the study is astringent (Bagozzi \& Yi, 1988) ${ }^{[32]}$. The average variance extraction (AVE) extracted between the potential variables and all the corresponding questionnaires is above 0.50 , which also means the convergence validity. The AVE values of the variants in this study ranged from 0.55 to 0.65 , indicating that the scales had acceptable convergence validity. The criterion for distinguishing the validity test is that the AVE square root of each variable in the scale is larger than the correlation coefficient between the variable and other variables (Hair et al., 1998) ${ }^{[33]}$. From Table 2, the square root of the AVE of each variable is $0.74 \sim 0.81$, which is larger than the correlation coefficient between the variables, showing that the scale of this study has good discriminant validity.

Table 1 Results of the validation factor analysis

\begin{tabular}{|c|c|c|c|c|c|}
\hline Construct & Item & $\begin{array}{l}\text { Mea } \\
\mathrm{n}\end{array}$ & SFL & $\mathrm{CR}$ & $\begin{array}{l}\text { AV } \\
\text { E }\end{array}$ \\
\hline \multirow{4}{*}{$\begin{array}{l}\text { Brand } \\
\text { trust }\end{array}$} & $\begin{array}{l}\text { I bought the brand of green products is } \\
\text { worthy of trust }\end{array}$ & 3.13 & $0.71 *$ & 0.83 & 0.55 \\
\hline & $\begin{array}{l}\text { I bought the green product brand is } \\
\text { worthy of dependency }\end{array}$ & 3.48 & $0.73 *$ & & \\
\hline & $\begin{array}{l}\text { I think what I am buying is an honest } \\
\text { brand }\end{array}$ & 3.30 & $0.75^{*}$ & & \\
\hline & I think the brand I bought is safe & 3.92 & $0.78 *$ & & \\
\hline \multirow{4}{*}{ Satisfaction } & $\begin{array}{l}\text { I think the purchase of green products can } \\
\text { meet my needs }\end{array}$ & 3.85 & $0.74 *$ & 0.87 & 0.62 \\
\hline & $\begin{array}{l}\text { I think buying green products is a wise } \\
\text { choice }\end{array}$ & 4.19 & $0.82 *$ & & \\
\hline & $\begin{array}{l}\text { Buying green products makes me feel } \\
\text { good }\end{array}$ & 4.19 & $0.82 *$ & & \\
\hline & $\begin{array}{l}\text { Buying green products makes me feel } \\
\text { very happy }\end{array}$ & 4.02 & $0.76^{*}$ & & \\
\hline \multirow{3}{*}{$\begin{array}{l}\text { Repurchase } \\
\text { intention }\end{array}$} & I will buy a green product is highly likely & 4.09 & $0.81 *$ & 0.85 & 0.65 \\
\hline & $\begin{array}{l}\text { There is a need to buy, I will first } \\
\text { consider the purchase of green products }\end{array}$ & 4.03 & $0.84 *$ & & \\
\hline & I am willing to buy green products again & 4.22 & $0.77 *$ & & \\
\hline
\end{tabular}

Note: $*: p<.05 ;$ SFL: standard factor loading; CR: composite reliability; AVE: average variance extracted.

Table 2 Correlation coefficients for each potential variable

\begin{tabular}{llll}
\hline & Brand trust & Satisfaction & $\begin{array}{l}\text { Repurchase } \\
\text { intention }\end{array}$ \\
\hline $\begin{array}{l}\text { Brand trust } \\
\text { Satisfaction }\end{array}$ & $\mathbf{( 0 . 7 4 )}$ & $\mathbf{( 0 . 7 9 )}$ & \\
$\begin{array}{l}\text { Repurchase } \\
\text { intention }\end{array}$ & $0.51^{*}$ & $0.65^{*}$ & $\mathbf{( 0 . 8 1 )}$ \\
\hline $\begin{array}{l}\text { 注: } * p^{*} .05 ; \text { The value on the diagonal (bold in brackets) represents the square root of AVE; the value below the } \\
\text { diagonal is the normalized correlation coefficient. }\end{array}$
\end{tabular}


The Overall Structure of the Model Analysis. This study was conducted by LISREL 8.7 software. After the analysis of the confirmatory factors, it is confirmed that the scale of each variable has good reliability and validity, so the model verification will be analyzed with these variables and items.

The results of the study hypothesis are as follows: $\chi^{2}=198.86, \mathrm{df}=41, \chi^{2} / \mathrm{df}=4.85$, GFI $=0.89$, $\mathrm{CFI}=0.92, \mathrm{IFI}=0.92, \mathrm{NFI}=0.95, \mathrm{SRMR}=0.025, \mathrm{RMSEA}=0.069$. The above numerical values show that the fit between the sample data and the hypothesis model is acceptable. The relationship between the variables and the results of all hypothesis test will be presented in Figure 2, respectively.

Fig. 2 shows that brand trust positively affects product satisfaction $(\gamma=0.57, p<0.05)$, so the hypothesis is established. The results of this study are consistent with Ha and Perks (2005) [17] and Wu Zongyou (2008) [25]. When consumers are aware that the brand of green products to be purchased is trustworthy, most consumers will feel the purchase of the product is a wise choice and feel satisfied. Lin Nanhong et al. (2007) [28], which shows that consumers are interested in the product, and the results are consistent with those of Chaudhuri \& Holbrook (2001) [15] and Lin Nanhong et al. (2007) [28] trust may increase the willingness to repurchase the product. Satisfaction positively affects the willingness to buy $(\gamma=0.76, p<0.05)$, so the hypothesis is true. This study confirms that consumers are more satisfied with the product and can increase their willingness to buy. The results of the study are in line with the findings of Brakus, Schmitt and Zarantonello (2009) [29], Yoon, Lee and Lee (2010) [30], Lai et al. (2009) [7], which are sensible when consumers think they are buying the product when the purchase needs will give priority to the purchase of the product.

To further explore whether the consumer satisfaction with the product also play a certain role in mediation, from table 3 that satisfaction with the former variable and the outcome of the variable between the role played. First, the indirect relationship between brand trust and repurchase intention is 0.43 , and reaches a significant level $(\mathrm{p}<0.05)$, meaning that brand trust can indirectly affect the willingness to repurchase by satisfaction, so hypothesis four holds. This study confirms that satisfaction has an intermediary role between brand trust and repurchase intention. When consumers have a sense of trust in the green product brand, consumers will be with the satisfaction of the

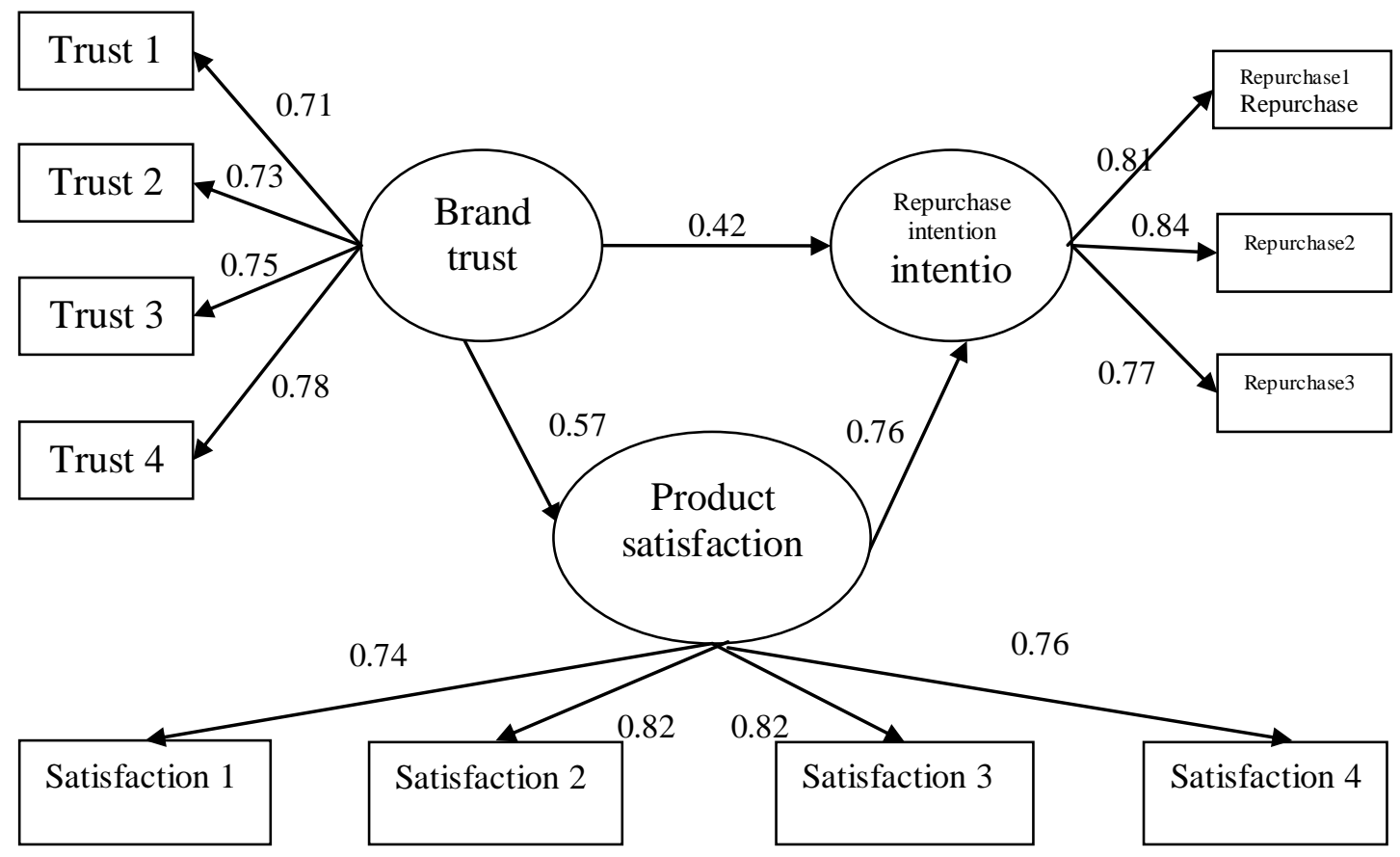

Figure 2. Schematic diagram of the structural equation product and strengthen their own re-purchase of the product will. 
Table 3 Direct and indirect effects of overall structural pattern analysis

\begin{tabular}{|c|c|c|}
\hline \multirow{2}{*}{ Independent variable } & \multicolumn{2}{|c|}{ By variable } \\
\hline & Product satisfaction & Repurchase intention \\
\hline \multicolumn{3}{|l|}{ Brand trust } \\
\hline Direct effect & $0.57^{*}$ & $0.42 *$ \\
\hline Indirect effect & -- & $0.43 *$ \\
\hline Total effect & $0.57 *$ & $0.85^{*}$ \\
\hline \multicolumn{3}{|l|}{ satisfaction } \\
\hline Direct effect & & $0.76^{*}$ \\
\hline \multicolumn{3}{|l|}{ Indirect effect } \\
\hline Total effect & & $0.76^{*}$ \\
\hline
\end{tabular}

\section{Conclusions and Recommendations}

Green consumption behavior has become the focus of discussion in recent years. However, the discussion area is rarely based on the consumption of green products. This study tries to understand the causal relationship between consumer trust and satisfaction of green products.

Conclusion. Through theoretical and empirical research, this study holds that consumer trust is a very important factor in the satisfaction of green products. If the brand trust of green products is higher, the satisfaction rate and the willingness of re-purchase will be higher, Once the consumer that the brand trustworthy, long-term satisfaction with the benefits of green products, and finally when consumers have to buy the demand naturally give priority to the green products.

1, Consumers believe that the brand trust on the satisfaction and re-purchase will have an impact, so the green product industry should strengthen the marketing of green products to enhance the consumer's impression of green products, in order to truly play the role of green products and power.

2, Consumers for the green products to buy the results of high satisfaction, may be because consumers believe that the purchase of green products is a wise choice, thus affecting the follow-up remittance wishes. According to the satisfaction of the measurement of the content of the title, since the creation of a happy and good product to buy feelings, allowing consumers to believe that the purchase for a wise choice, and to enhance awareness of satisfaction, the industry should plan a good, health and safety Shopping environment, so that consumers will increase the future willingness to buy.

3 , When consumers perceive a higher degree of satisfaction, the action and frequency of the original behavior will be enhanced, so the re-purchase will increase. In this study, when consumers perceive the green product brand is worthy of trust, it will improve satisfaction. And satisfaction and re-purchase intention is a high correlation. So the brand trust will affect the re-purchase through satisfaction. Therefore, the industry should focus on product brand promotion and marketing, to enhance the brand-related effects and impressions, but also take into account the consumer satisfaction with the product to enhance its willingness to buy.

Related Recommendations.In addition to providing the following management implications for the green product operators, this study also provides future research recommendations for further study.

1 , whether consumers are willing to buy after buying the product, has been the primary concern of business operators, how to promote consumers willing to buy after buying the green products, 
product satisfaction is a key. So the green product industry should create a pleasant shopping environment, thereby increasing the willingness of consumers to buy.

2 , the first to establish consumer trust in the brand, for example, the production process and raw material source transparency, and put forward production and sales experience or proof of certification, so that consumers think the brand is trustworthy and safe. Second, shaping the positive image of green products, such as active participation in social welfare and good corporate social responsibility, will help consumers to the satisfaction of green products.

Study Restrictions and Follow-up Researchers Advice. Based on the convenience and limited resources of the sample, only 416 samples were collected, but the investigation was carried out for the whole of Taiwan. Therefore, the results of this study were not biased, but this study makes the sampling method and design there are some restrictions. It is recommended that follow-up researchers can further expand the investigation or study for different age groups to understand the consumer groups on the intention of consumption of green food.

Therefore, this study only discusses the relationship between brand trust, satisfaction and willingness to repurchase. However, many related brand variables, such as: brand knowledge, brand image, brand personality and brand equity. Green product issues There are many more worthy of research, it is recommended to explore other brand variables to increase knowledge of green product management.

\section{References}

[1] F.P. Cao, L.Y. Wen et al. Experimental analysis of the relationship between green management, O.190, p.117corporate image and competitive advantage: East China Economic Management, Vol. 26 (2012) N.

[2] J. Elkington and J. Hailes: The green consumer(Viking Penguin, USAand1993).

[3] K. Peattie: Green Marketing ( Pitman Publications, Londonand1992).

[4] Information on http://gtllab.iaalab.ncku.edu.tw /gpcd/unit_type.asp?Unit=1\&Type=5 .

[5] C. D'Souza. Bridging the communication gap: Dolphin safe eco-labels: Corporate Communication: An International Journal, Vol. 5 (2000) No.2, p.185.

[6] E. W. Anderson, C. Formell and D. R. Lehmann. Customer satisfaction, market share, and profitability: Findings from Sweden: Journal of Marking. Vol. 58 (1994) p.53.

[7] W. B. Dodds, K. B. Monroe and D. Grewal. Effects of price, brand, \& store information on buyers' product evaluations: Journal of Marketing Research. Vol. 28 (1991) No.3, p.307.

[8] F. Lai, M. Griffin, and B. J. Babin. How quality, value, image, \& satisfaction create loyalty at a Chinese telecom: Journal of Business Research, Vol. 62, (2009) p. 980.

[9] R. Russell-Bennett, J. R. McColl-Kennedy and L. V. Coote. Involvement, satisfaction \& brand loyalty in a small business services setting: Journal of Business Research, Vol. 60 (2007) p.1253.

[10] Information on http://pt.wikivoyage.org/wiki/P\%C3\%A1 gina_principa.

[11] S. Lockie, K. Lyons and G. Lawrence. Constructing "green" foods: Corporate capital, risk, and organic farming in Australia and New Zealand: Agriculture and Human Values, Vol.17 (2000) No.4, p.315.

[12]H. Nash. The European commission's sustainable consumption \& production \& sustainable industrial policy action plan: Journal of Cleaner Production, Vol. 17 (2009) No.4, p.496. ,

[13] Y.W. Fan, Y.X. Fang, M.F. Cai. Explore the willingness to consume green products: the effect of environmental labeling: Journal of e-Business, Vol.14 (2012) No.2, p.257.

[14] P. C. Lin and Y. H. Huang. The influence factors on choice behavior regarding green products based on the theory of consumption values: Journal of Cleaner Production, Vol.22, (2012) p.11.

[15] A. Chaudhuri and M. B. Holbrook. The chain of effects from brand trust and brand affect to brand performance: The role of brand loyalty: Journal of Marketing, Vol.65 (2001) No.2, p.81. , 
[16] Delgado-Ballester, E. (2004). Applicability of a brand trust scale across product categories. European Journal of Marketing, 38(5/6), 573-592.

[17] H. Y. Ha and H. Perks. Effects of consumer perceptions of brand experience on the web: Brand familiarity, satisfaction and brand trust: Journal of Consumer Behaviourval, Vol.4 (2005) No.6, p.438.

[18]E. Delgado-Ballester and J. L. Munuera-Alemán. Does brand trust matter to brand equity? : Journal of Product \& Brand Management, Vol.14 (2005) No.3, p. 187.

[19] M. D. Johnson and C. Fornell. A framework to compare customer satisfaction across individual and product categories: Journal of Economic Psychology, Vol.12 (1991) p.267.

[20]R. D. Blackwell, P. W. Miniard and J. F. Engel: Consumer behavior (9th Ed.) (Harcourt College Publishers, the United Statesand2001).

[21] Y. He and H. Song. A mediation model of tourists' rererepurchase intentions for packaged tour services: Journal of Travel Research, Vol.47 (2009) No.3, p. 317.

[22] V. A. Zeithaml. Consumer perceptions of price, quality, \& value: A means-end model \& synthesis of evidence: Journal of Marketing, Vol.52 (1988) No.3, p.2.

[23] C. Moorman, G. Zaltman and R. Deshpande. Relationship between providers \& users of market research: The Dynamics of trust within a between organizations: Journal of Marketing Research, Vol.29 (1992), p.317.

[24]L.G. Schiffman and L. L. KanukConsumer Behavior: (Prentice Hall Upper, Saddle River, New Jerseyand2000).

[25]Z.Y. Wu. Responsibility and Organizational Commitment of Authoritarian Leadership and Subordinate: Trust Mediation Process and Emotional Intelligence Modification Effect: Local Psychology Research, Vol.30 (2008) No.1, p.3.

[26] J. Lee, A. R. Graefe and R. C. Burns. Examining the antecedents of destination loyalty in a forest setting: Leisure Sciences, Vol.29 (2007) p.463.

[27]H. Oh. Service quality, customer satisfaction and customer value: A holistic perspective: International Journal of Hospitality Management, Vol.18 (1999) p.67.

[28] N.H. Lin, W.Z. Wang, S.Y. Qiu et al. Product Knowledge and Brand Image Impact on Repurchase Wishes - Interference Effects of Product Categories: Marketing Review, Vol.4 (2007) No.4, p.481.

[29] J. Brakus, B. H. Schmitt and L. Zarantonello. Brand experience: What is it? How is it measured? Does it affect loyalty?: Journal of Marketing, Vol.73 (2009) p.52.

[30] Y. S. Yoon, J. S. Lee and C. K. Lee. Measuring festival quality and value affecting visitors' satisfaction and loyalty using a structural approach: Journal of Hospitality Management, Vol.29 (2010) p.335.

[31] S. Hosany and D. Martin. Self-image congruence in consumer behavior: Journal of Business Research, Vol.65 (2012) p.685.

[32]R. R. Bagozzi and Y. Yi. On the evaluation of Structural Equation Models: Journal of the Academy of Marketing Science, Vol.16 (1988) No.1, p.74.

[33] J. F. Hair, R. E. Anderson, R. L. Tatham et al. Multivariate Data Analysis (5th ed.): (Englewood Cliffs, NJ: Prentice Halland1998). 